\title{
MENUJU KESETARAAN DALAM BERAGAMA YANG BERBUDAYA: REFLEKSI SEMINARIAN INJILI
}

\author{
Togardo Siburian \\ Sekolah Tinggi Teologi Bandung
}

\begin{abstract}
This article discusses a variety of modern man who is more civilized from the Evangelical perspective. Nowadays, the relations between different religious people is still filled with religious violence and conflicts. This happens because of extreme radicalism views which perhaps are caused by the leftovers of our religious studies and practices in the past. There was a misunderstanding in professing religion which could destroy the future of human civilization due to the absence of a culture of togetherness. The Evangelical Christianity may participate to think few principles of religious life which are better for present humanity. The recommended principles are: 1) the importance of natural religious comparison in the normal society, 2) returning to the principle of missional church, 3) prioritizing the ethical emphasis more than the apologetical, 4) the balance between faith commitment and religious tolerance, 5) prophetic leadership rather than priesthood only, 6) faith particularism than religious exclusivism in inter-religious approach, 7) personal spirituality rather than individual religiosity. Thereby it is hoped that religious people may live together easier within the context of national unity and world peace.
\end{abstract}

KEYWORDS: religious, conflict, collective civilization, normal comparison, ethical, prophetic, missional, particular.

ABSTRAK: Tulisan ini sedang mewacanakan suatu keberagamaan manusia modern yang lebih berkeadaban dari perspektif injili. Sekarang, relasi antarumat beragama masih dipenuhi kekerasan agama dan konflik. Hal ini karena paham-paham radikalisme ekstrim, yang mungkin akibat sisa-sisa 
kajian dan praktek studi agama-keagamaan kita di masa lalu. Ada kesalahpahaman dalam beragama yang bisa menghancurkan masa depan peradaban manusia, karena absennya budaya kebersamaan. Kekristenan injili dapat berpartisipasi memikirkan beberapa prinsip kehidupan beragama yang lebih baik bagi masyarakat manusia masa kini. Prinsipprinsip yang direkomendasikan itu adalah: 1) pentingnya perbandingan agama natural dalam masyarakat normal, 2) kembali pada prinsip gereja misional, 3) mendahulukan penekanan etis dibanding apologetis, 4) keseimbangkan komitmen iman dan toleransi beragama, 5) kepemimpinan kenabian dibanding keimamatan saja, 6) pendekatan partikularisme iman dibanding eksklusivisme agama dalam pendekatan antaragama, 7) spiritualitas personal dibanding religiusitas individual. Dengan demikian diharapkan umat beragama dapat lebih mudah hidup bersama dalam kesatuan bangsa dan kedamaian dunia.

KATA KUNCI: beragama, konflik, peradaban bersama, perbandingan normal, etis, profetis, misional, partikular.

\section{Pendahuluan}

Sejak semula kita meyakini bahwa manusia adalah makhluk agama sekaligus makhluk sosial. Terlepas dari diri orang itu mau atau tidak mau bersosialisasi dengan baik dalam praktek: non-sosial, anti-sosial; juga sebagai makhluk beragama terlepas dari nama, bentuk, dan cara keberagamaan, formal atau non-formal. Terkait dengan keduanya, masih ada satu lagi postulat berkemanusiaan di dunia ini, yaitu sebagai makhluk budaya, yang terdiri dari makhluk bekerja (homo-laborans) dan makhluk berpikir (homo-sapiens) bahkan makhluk akademis. Itu semua membuat manusia layak disebut "makhluk adab". Sebagai makhluk hidup yang berperadaban, seyogianya manusia berbudaya luhur dalam relasi-relasi antarindividu yang berbeda, di dalam masyarakat. Normalnya, "manusia 
modern" dalam arti "maju" secara intelektual (bukan hanya akademis) dapat mengatasi ekses (negatif) beragama dari relasi antar-personalnya dalam kehidupan majemuk. Ini adalah keunikan masyarakat manusia beradab, yaitu dapat bersepakat dalam perbedaan dan saling menghargai dalam toleransi.

Bila melihat benturan umat beragama dalam bermasyarakat sekarang, kelihatannya tidak ada perubahan yang signifikan dalam tata kehidupan masyarakat agama. Walaupun pengetahuan akademik manusia lebih maju dalam tema-tema keagamaan manusia, tetapi tidak serta-merta membuat budi pekerti manusia lebih dewasa dalam berpikir tentang peradaban manusia. Ternyata tingginya pendidikan manusia yang tampak dari gelargelar mentereng dengan fokus kemajemukan agama, tidak dapat mengubah cara pandang dalam meredakan konflik yang diakibatkan perbedaan. Bahkan mereka terkesan justru mempercanggih permusuhan agama, karena fanatisme buta para penganut agama dan memutakhirkan studi kita dalam persaingan agama secara global. Alhasil, kita memandang dunia semakin suram sampai putus harapan, bahwa "perdamaian agama tidak mungkin dapat terwujud". Situasi dan kondisi dunia semakin kritis.

Walau pesimis, kekristenan injili harus memikirkan ulang jalan perdamaian yang lebih patut untuk merumuskan pemikiran yang lebih moderat demi solusi-solusi yang lebih berani. Usaha itu, paling tidak untuk mengurangi konflik dengan niat baik yang dimulai dari diri sendiri, namun tetap setia dalam keunikan iman nya. Di sinilah pentingnya refleksi teologis atas persoalan-persoalan kehidupan umat beragama yang berbudaya. Sebagai seminarian injili, kita diingatkan untuk melebarkan hati dan membuka pikiran. Ini adalah sebagai panggilan nasional dan global, masa kini.

Untuk itu kita harus menggambarkan dulu secara eksploratif kondisi dan situasi masyarakat agama sekarang, lalu memikirkan prinsip-prinsip kebersamaan di dalam beragama, yang mungkin selama ini terabaikan oleh 
kaum injili.

\section{Kondisi dan Situasi Kritis Keberagamaan Kita}

\section{Anasir Jahat dalam Agama Manusia: Kondisi Riil}

Adalah suatu realitas bahwa unsur religius sebagai keunikan umat manusia itu membawa ekses negatif dalam kehidupan bermasyarakat, sehingga manusia harus memikirkan hakikatnya kembali dalam peran sebagai makhluk moral. Apalagi kekhususan manusia adalah makhluk agama juga, yang dianggap sebagai faktor baik dalam kehidupan umat manusia, karena terkait dengan kesucian ilahi dan kebaikan moral religius. Namun, justru unsur religius itu membawa ekses negatif dalam peradaban manusia, sehingga manusia harus memikirkan kembali peran moralnya sebagai makhluk religius. Tidak seperti moral alamiah yang seringkali tanpa batas-batas nilai yang relatif dari dirinya sendiri (manusia), maka moral agama seharusnya memainkan peranan penting dalam kemanusiaan.

Untuk itu, manusia masa kini harus menyadari dirinya sebagai "makhluk religius" dalam suatu kebudayaan yang luhur dan terus selalu mengingatkan, agar tidak keluar dari konsep-konsep kesucian agamanya. Karena keberadaan agama dituduh sebagai "anasir jahat" yang dipakai untuk melukai sesama manusia, karena sikap dan hati saling membenci berkepanjangan dari ajaran agama. Beberapa orang sering berdalih, bahwa konflik itu dikarenakan soal penafsiran agama yang melenceng oleh kaum ekstrimis, bahkan sampai pada penilaian agama itu sendiri mengandung jahatnya sendiri-sendiri. ${ }^{1}$ Secara teoritis hal ini pernah diakui juga, walau

\footnotetext{
1 Wacana ini dapat dilihat lagi dalam "Agama, Masyarakat dan Peradaban": dalam Societas Dei Jurnal Agama dan Masyarakat Vol. 1 no. 2 (Agustus 2014): di sini dipersoalkan apakah agamanya yang salah atau orangnya yang salah dalam analogi man behind the gun (atau gunnya). Pada kesempatan ini kalau agamanya yang mengajarkan kesalahan memang tidak ada harapan bagi umat manusia sekarang. tetapi kalau soal manusianya yang salah menafsirkan maka mungkin masih ada harapan, asalkan manusia terdidik dalam hidup bersama.
} 
tidak sepenuhnya soal efek agama. Menurut profesor ilmu budaya UGM, Loekman Soetrisno dalam bukunya yang berfokus kasus di Indonesia, "Agama merupakan wahana yang sangat efektif untuk memobilisasi massa...guna mencapai tujuan negatif seperti penyebab konflik (karena), walaupun di halaman lain beliau berpendapat agama bukanlah penyebab utama konflik di masyarakat, namun "agama adalah salah satu faktor penyebab dari sekian banyak faktor yang menjadi penyebab konflik," misalnya "Birokrasi yang tidak teratur dan kesenjangan sosial antarkelompok dan ketidakberdayaan ekonomi politik yang tinggi."2 Di sini cukup diakui bahwa agama dapat menjadi faktor potensial untuk mendinginkan nurani manusia dan sangat berbahaya dalam relasi-relasi antarumat yang berbeda, untuk menjadi sarana permusuhan dalam hati.

Kaum beragama, termasuk Kristen (khususnya injili) harus menyadari bahwa perbedaan bukan selalu berarti pemisahan sosial dari masyarakat. Keberagamaan seharusnya tidak menjadi kutuk dalam kehidupan manusia, melainkan menjadi berkah untuk saling memperkuat tolong-menolong dalam kehidupan bersama. Manusia seharusnya dapat mendasarkan moralnya pada standar yang otoritas berasal dari luar dirinya agar keberagamaannya dapat berkemanusiaan. Prinsip moral bersumber dari Sang Pencipta yang suci dan kekal maka prinsipnya bernilai universal.

\section{Radikalisme dalam Keberagamaan Kita: Situasi Faktual}

Ini terlihat dalam situasi bangitnya fenomena terorisme, fundamantalis, bahkan ISIS sampai Boko Haram yang global dan sudah mempengaruhi situasi regional dan nasional suatu negara tertentu. Tempo.co dalam suatu survei interaktif pernah mengajukan pertanyaan: "Percayakah Anda kelompok dan pendukung radikalisme akan berkembang di

2 Loekman Soetrisno, Konflik Sosial, Studi Kasus Indonesia (Yogyakarta: Tajidu Press, 2013), 359. 
Indonesia?" Dari 544 responden, sebanyak 351 (64,5\%) menjawab "ya". Sebanyak $180(33,1)$ menjawab "tidak". Sisanya, 13 orang $(2,4 \%)$ tidak tahu. Perhatikan diagram di bawah ini $^{3}$

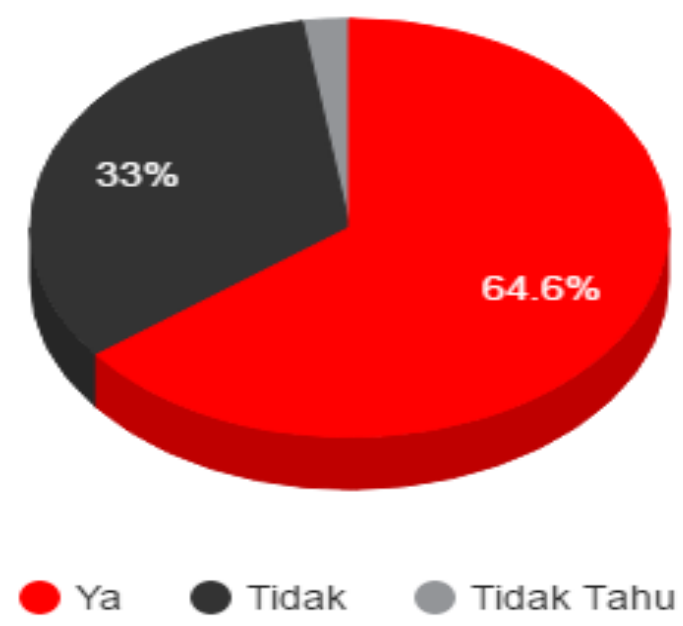

Ini suatu data penting, yang kalau ditafsirkan dari kenyatan riil yang ada dalam aras nasional memang memprihatinkan bangsa. Ada krisis besar juga walau potensial. Berdasarkan survei itu dapat ditafsirkan dari total reponden yang biasanya lebih dari 2.000 orang per periode jajak pendapat, namun sekarang hanya separuhnya. Di sini muncul pertanyaan, apakah ada satu keengganan untuk menjawab ini karena kondisi riilnya memang sedang terjadi pada aras bawah masyarakat kita. Apakah mungkin 33,1 persen itu justru kebanyakan kategori laten melakukan lalu menjawab "tidak", dan 54 persen yang menjawab "ya" adalah kebanyakan korban dari kegiatan radikal dan secara laten merasa memang semakin meningkat.

3 Tempo.co. (diakses 25 September 2016). Lihat juga rubrik "Indikator" dalam Majalah Tempo 26 September - 2 Oktober 2016. 
Apa yang disebut sebagai radikalisme atau fundamantalisme selalu bersifat negatif dan merusak masyarakat dan kemanusiaan secara umum. Selain itu masalah diskriminasi agama semakin besar, baik itu secara nyata atau dalam sanubari. Di masyarakat sering terdengar cetusan, “Tidak apaapa pemimpin jahat atau korupsi asalkan seagama". Menjelang pilkada saat ini saja sedang marak himbauan untuk tidak memilih calon pemimpin dari agama lain, karena dilarang ajaran agama. Bahkan mungkin ada banyak orang yang diam-diam membela orang yang berbuat jahat, karena sealiran dan seagama. Sehingga beragama bukan lagi mengejar kebajikan kemanusiaan, melainkan sebagai sumber kerusakan manusia, bahkan agama menjadi alat yang paling kejam untuk menghancurkan kehidupan berbangsa.

Dalam artikel utama majalah Tempo bulan September 2016, menggambarkan dengan jelas sikap-sikap masyarakat berwarga negara lewat hasil survei Wahid Foundation: Sebanyak 7,7 persen responden bersedia ikut kegiatan radikal agama, termasuk seperti menyerang rumah ibadah agama lain. Bahkan 47,9 persen bersikap keberatan jika orang yang tidak seagama menjadi pemimpin (dibanding 41,7 persen yang tidak keberatan). Demikian juga 52 persen bersikap keberatan terhadap pembangunan rumah ibadah agama lain. ${ }^{4}$ Saya kira polling interaktif itu juga dijawab oleh banyak responden dari agama berseberangan untuk pendapat yang berlawanan (pada prosentase perbandingannya). Ini menggambarkan bahwa ternyata diskriminasi agama masih terus terjadi di zaman yang begini maju dalam pendidikan dan intelektualitas, yang bisa menghantam masa depan bangsa.

\footnotetext{
4 Majalah Tempo 11 September 2016, 34-37. Lih. juga di dalamnya masih ada fakta-fakta berguna lainnya yang sebenarnya tidak mengejutkan dalam menggambarkan masyarakat agama kita sekarang, baik secara nasional dan global.
} 


\section{Neo Oriantalisme sebagai Sisa-sisa Peradaban Masa Lalu}

Mendalami cara Orientalisme "Barat melihat dunia Timur", "usahanya dalam memahami bahasa dan kebudayaan Timur" adalah untuk usaha "perdagangan, pertentangan antaragama, dan konflik militer". Ternyata kelak pengetahuan tentang Timur tidak dapat dipisahkan dari sejarah ekspansi Eropa di Asia ... Orientalisme itu sendiri adalah suatu semangat menuju ke Timur dengan "prinsip kontras dan perbandingan" 5 dengan "melihat persaman dan perbedaan agama, dalam hal ini orientalis lebih menekankan "Bagaimana kebudayaan Barat melihat dunia Islam."6 Secara idealisme, pola ini masih dibawa sampai sekarang, di mana dunia Timur identik dengan Islam, sedangkan konsekuensi logisnya dunia Timur melihat dunia Barat sebagai Kristen. Alhasil, sampai sekarang agama Kristen di dunia Timur dikategorikan agama Barat yang dicap "agama penjajah" yang patut dimusuhi, karena faktor historis kolonialisme dan imperialisme di masa lalu. Di sinilah saatnya kita harus lepaskan label-label politis yang merusak pada agama-agama.

Selama ini tema-tema keberagamaan yang berbudaya sudah sering dan lebih dari cukup dibicarakan. Namun tidak ada hasil maksimal juga, karena budaya didominasi oleh pemikiran sempit tentang segolongan identitas. Wacana multikulturalisme tidak meluas sampai pada pemikiran konsep-konsep filosofis menuju keberadaan manusia yang lebih esensial, yang disebut "peradaban". Selama ini apa yang dipelajari di Barat, budaya selalu dipelajari dari ilmu antropologi belaka, yang secara khusus berfokus pada etnik-etnik tertentu yang dianggap primitif. Ilmu Barat masih melihat budaya secara antropologi tertentu, yang hasilnya sering dipakai untuk

\footnotetext{
5 Bryan S. Turner, Relasi Agama dan Teori Sosial Kontemporer terj. (Yogyakarta: ICRiSoD, 2003), 44.

6 Ibid., 18. Di sini muncul label orientalis Barat seperti Islam sebagai "agama perang"; Budha sebagai "agama apolitis" (403), namun tidak berhasil mengidentifikasi Kristen sebagai "agama penjajah" sebagai label dari non-Barat.
} 
bahan ilmu penyebaran agama ke seberang lautan dalam usaha penambahan populasi agama. Di sini pelajaran multikulturalisme Barat telah menyebabkan peradaban manusia terkotak-kotak dalam suatu konflik yang lebih besar dalam persaingan agama. Syukurlah sekarang di lingkungan akademik Indonesia, dengan ilmu (ke)budaya(an) yang diidentikkan ilmu filsafat atau setidaknya dimasukkan ke dalam ilmu filsafat, sehingga lebih berfokus pada nilai-nilai universal dalam kemanusiaan dan perikemanusiaan. Itu adalah jalan baik menuju prinsip budi pekerti luhur peradaban manusia sekarang dan untuk masa depan, yang tentunya bukanlah untuk utopia agama saja, tetapi suatu pertanggungjawaban umat beragama.

Peradaban global telah terkotak-kotak secara kontroversial dan saling berperang dalam ideologi politik dunia, misalnya, antara peradaban dunia Barat versus dunia Timur (atau ekonomi dunia Utara versus Selatan), bahkan sekarang dikembangkan secara tidak benar dalam konfrontasi peradaban dunia Barat versus dunia Islam. Padahal yang terakhir itu sebenarnya tidak logis, karena kedua entitas itu berbeda, yang satu dari perspektif dunia politik-ekonomi diperlawankan dengan dunia agamapolitik. Konsekuensinya dapat diterka, minoritas agama, Kristen misalnya, akan tertindas karena sentimen anti-Barat. Sementara sampai sekarang, dunia intelektual Barat mendiskusikan suatu bentuk dialog perbandingan agama yang mutakhir, lalu diikuti dan digemari oleh para pelajar Timur yang belajar di dunia Barat. Padahal konteks riil dan aktual pemikiran teologis di Barat tentang agama keagamaan sangat berbeda dan bertolak belakang dengan non Barat.

\section{Pentingnya Beragama yang Berbudaya dan Berperadaban}

Hidup Beragama sebagai Hidup Berbudaya

Sejalan dengan esensi keagamaan yang mempengaruhi kehidupan 
manusia, baik secara individual maupun komunal di dalam kebiasaankebiasaan umum budayanya. Manusia sebagai "makhluk budaya" yang beragama akan mempengaruhi keseluruhan kehidupan, baik dalam proses: pemikiran, perkataan, tindakan pribadi, perubahan sosial, dll. Dalam konteks ini biasanya disebut menjadi "system kepercayaan". Secara antropologis, kebudayaan adalah semacam cara pandang seseorang ketika bertindak dalam berkehidupan, berbicara, berpikir, dan lain lain. Agama sangat mempengaruhi budaya manusia sebagai suatu sistem simbol yang beraksi untuk mempengaruhi dan membentuk cara-cara manusia dalam tindakan dinamis sehari-hari. Pendekatan antropologi akan memfokuskan manusia dalam budaya, termasuk budaya beragama. Jadi kajian simultan antara agama dan kultur sangat penting para era ini dalam prinsip prinsip dasar berikut ini:

1) Religion is studied as a human activity. In short, religion is a part of culture.... 2) The study of such 'religion' is concerned with what humans do, the texts and other cultural products they produce, and the statementsand assumptions they make.... 3) 'Religion' is a not a sui generis category, that is, it does not exist as a 'thing' in itself... 4) The study of religion and culture is based on methodological pluralism and interdisciplinarity.... 5) There is a strong emphasis on studies with an empirical basis. Although there are many abstract and philosophical issues raised in the study of religion and culture, ... 6) As religion is a human activity, the analysis of religion and culture is the analysis of gender, ethnicity, and other socialrelations and categories... 7) The study of religion and culture is cross-cultural, multicultural, and postcolonial. The discipline is located in a global context of... 9) The use of the concept (or category) of religion is culture bound-it is itself a product of these histories and political Processes... 10) The study of religion and culture is highly relevant to our understanding of the contemporary world. Religion is a key element of many cultural issues, as well as a significant factor in the historical development of the worlds and contexts in which we live. ${ }^{7}$ 7 Malorie Nye, Religion: The Basics (London, New York: Routledge Park Square, 2nd Edition,
2008), 20-21. 
Nomor 7 harus diwaspadai untuk kemunculan neo-orientalisme tersembunyi dalam kajian multikulturalisme yang sangat westernik di nonBarat pascakolonialisme dan imprialisme sekarang. Sedangkan poin 9 dan 10 adalah pembahasan langsung tulisan ini era pascamoden ini untuk peradaban manusia. Artinya, dapat dikatakan bahwa bahasan agama-agama global sangat spesial pada era ini.

Andy Crouch melihat proses kebudayaan berdasarkan implikasi religius dari studi Sosio-Antropologis Peter L. Beger, yang mengatakan bahwa, "Setiap perkumpulan manusia adalah sebuah perjuangan untuk membangun dunia." Ini harus dilihat sebagai aksioma dalam kebudayaan manusia, di mana lebih lanjut bahwa "kebudayaan bukan sekadar usaha manusia membuat suatu arti dunia ini, atau sekadar cara manusia untuk mengerti dunianya; sesungguhnya kebudayaan adalah bagian dari dunia ini yang melaluinya setiap manusia [baru] harus membuat sesuatu"; yang selanjutnya dapat disimpulkannya sendiri. "Jadi budaya bersifat kumulatif."8 Itu adalah peradaban kebudayaan, bukan saling memakan dalam kreativitas ideologisnya dengan alasan kemajuan dari budaya-budaya tertentu. Sebenarnya itu hanyalah dalih kebodohan dan bukan alasan yang keluar dari kelogisan manusia. Ini suatu ironi dari studi budaya yang berprinsip manusia sebagai makhluk agama sekaligus makhluk sosial. Prinsip kumulatif adalah ciri peradaban maju, bukan sekadar progresif dan kreatif dari hasil seleksi alam dari budaya tertentu. Di sinilah istilah "peradaban" sering juga disandingkan dengan "kebudayaan" pada masa kini, khususnya dalam ilmu filsafat atau ilmu kebudayaan atau ilmu kemanusiaan yang berbudaya. Jadi ilmu budaya bukanlah selalu dan sekadar dalam etnologi budaya semata, tetapi ontologi dari kebudayaan manusia sebagai suatu bagian niscaya bagi peradaban dunia ini.

\footnotetext{
8 Lih. Andy Crouch, Menciptakan Kebudayaan: Menemukan Kembali Panggilan Kreatif Kita, terj.
} (Surabaya: Literatur Perkantas Jatim, 2011), 22 (lih. juga 23). 
Tetapi studi antropologi evolusionistik membuat antropologi agama memfokuskan kajiannya pada perubahan agama-keagamaan secara kultural. Artinya perkembangan bentuk agama manusia sejalan dengan kemajuan peradaban manusia, yang secara teoritis menghasilkan bentuk-bentuk agama melalui prinsip natural selection dan ajaran survival of the fittest kehewanan yang terterapkan dalam dunia manusia. Dikatakan di dalam teori seleksi, agama berdasarkan dunia rimba kebinatangan, agama ditegakkan berdasarkan prinsip hidup "memangsa atau dimangsa". 9 Ini suatu realitas 'aneh tapi nyata'; sebagai anomali dalam dunia beragama yang harus dihadapi secara akademis intelektual.

Faktanya, prinsip diatas dipakai oleh apa yang disebut dengan paham "eksklusivisme agama" sedang berjalan dalam teori keberagamaan yang demikian, dan secara tidak sadar menjadikan manusia beragama seperti binatang yang bertahan hidup di habitat buasnya. Pertanyaannya "Apakah memang manusia pada dasarnya adalah binatang?" Jawabnya "Tentu tidak!" Pertanyaannya lagi "Apakah posisi eksklusif yang didasarkan superiorisme agama, sedikit banyak sedang menunjang prinsip hidup dari sisa-sisa kebinatangan manusia? Padahal kita tahu, bahwa binatang bertindak tidak berdasarkan moral apalagi agama. Apa yang salah dalam agama manusia, selain dari egoisme beberapa pelopor atau sekelompok petualang agama yang melupakan hakekat keagamaan itu sendiri? Kelompok fanatik radikal beragama tersebut pasti akan kritis kalau manusia disamakan dengan binatang atau dalam beragamanya manusia masih mengandung sisa-sisa kebinatangan, seperti dalam prinsip teori evolusionisme kehewanan tersebut. Tentu manusia bukanlah hewan tingkat tinggi, tetapi ciptaan tertinggi dari Allah, yang nyata dalam faktor keilahian

\footnotetext{
9 George Bataille, Theory of Religion, terj. (New York: Zone Books, 1992), 17 dst., dijelaskan olehnya bahwa hubungan 'binatang dan dunia' dianalogikan sebagai 'air di antara air' jadi bersatu dan tidak dapat dipisahkan.
} 
dan bentuk-bentuk berkeagamaannya.

Secara teoritis dianggap, bahwa agama-agama formal selama ini -- di dalam sejarah-- muncul dari situasi "melenyapkan" agama yang lebih dulu di dalam unsur penyebarannya. Sampai sekarang pun masih ada nuansa konflik sebagai sisa-sisa konflik masa lalu dan sekarang berubah dalam pola baru permusuhan antaragama dalam apa yang disebut "radikalisme" atau "fundamentalisme". Bahkan pola konflik itu secara sengaja masih dipelajari dalam studi perbandingan agama, baik secara filosofis, antropologis, teologis (misiologis), sosiologis, psikologis, bahkan fenomenologis. ${ }^{10}$ Memang idealnya kajian itu untuk meredam konflik, karena informasi yang seimbang dari kajian-kajian tersebut. Namun faktanya, fenomena bentrokan keras antarumat beragama terus terjadi karena 'tidak ada satu pun agama yang mau dilenyapkan oleh agama lain.' Reaksi bertahan akan muncul dan menyerang balik jika dimungkinkan. Anomali keberagamaan manusia di dunia ini adalah faktor misioner yang mengandung arah-arah fanatismenya masing-masing. Karena pemikiran keagamaan selalu dapat muncul menjadi satu ideologi yang saling bersaing dan eksesnya adalah saling merebut pengikut/penganut agama. Pada titik ini para pemuka agama berusaha mengumpulkan pengikut dan menjadikan jumlah penganut sebagai suatu obsesi demi kebanggaan pragmatisme belaka.

Ini adalah situasi kritis di dalam manusia masa kini yang diakibatkan ajaran "superiorisme agama atas agama-agama lain" dengan dalih "eksklusivisme agama di dalam masyarakat". Kedua prinsip untuk pendekatan agama-agama ini sudah membudaya dalam kompetisi agamaagama sampai sekarang, termasuk budaya superiorisme Barat melalui prinsip keagamaan ekstrim selama ini. Jadi kemungkinan keberagamaan

\footnotetext{
10 Bagi yang ingin melengkapi pemikiran saya di sini dapat melihat "Studi Perbandingan Agama Sebagai Benih Penghancuran Umat Manusia [sekarang]: Perspektif Injili” dalam Jurnal Teologi Stulos Vol. 10 No. 1 (April 2011): 117-40.
} 
manusia yang negatif sekarang ini, diturunkan dari budaya-budaya manusia di dalam perjalanan peradaban ras bangsa-bangsa di dunia, bukan dari dalam diri keagamaan itu sendiri. Selanjutnya agama-agama yang terdistorsi budaya negatif dan peradaban tersebut akan mempengaruhi balik kehidupan manusia secara siklus, seperti lingkaran setan. Pendeknya, keberadaan agama-agama muncul silih berganti berdasarkan prinsip kekerasan dan pembunuhan terhadap agama sebelumnya di dalam sejarah manusia. Tentunya pernyataan ini rentan untuk diduga sebagai provokasi bagi prinsip rivalisme dan superioritas dalam agama-agama modern sekalipun.

Biar bagaimanapun tidak semua budaya yang dihasilkan peradaban manusia itu berbudi luhur, karena faktanya banyak sisi-sisi "terkutuk' dari budaya-budaya bangsa dan etnik, lalu bercampur dengan ajaran agama yang cocok untuk keinginan manusia yang rusak. Hal itu menyebabkan keberagamaan dapat mempengaruhi secara negatif pada kesehatan mental [kejiwaan], seperti: kegilaan, obsesi, kecemasan, neurosis, schizofrenia, depresi, dll.; dan mungkin saja selalu diikuti oleh sikap fanatisme, intolerasi, egoisme...11 beragama dari orang tersebut. Salah satu paham fundamentalisme agama adalah contohnya pada masa kini, yang merusak tatanan sosial budaya dalam membudaya-politikkan agama dan mempolitik-agamakan budaya tertentu. Agama jadi melawan esensi dan eksistensinya sendiri, karena secara ontologis dan etisnya keagamaan terkait dengan sifat Allah yang suci berkontraskan dengan sifat Iblis - sebagai lawan-Nya-, yang diimajinasikan sebagai sifat: jahat, keji, tidak berbelas-

\footnotetext{
11 Ini adalah penafsiran berdasarkan survei Gallup Poll, yang pernah mengobservasi masyarakat sekular seperti Amerika pun, ternyata sebagian besar penduduknya mengaku bahwa agama sangat mempengaruhi kehidupan orang dewasa dalam tindakan, pandangan, dan perkataannya sangat religious, termasuk peran fungsional agama yang negatif. Harold G. Koenig, Is Religion Good for Your Health? The Effects of Religion on Physical and Mental Health (New York: The Howard Pastoral Press, 1997), 36-37.
} 
kasihan, penipu, penyesat, dll. Padahal dari entitasnya, semua bentuk dan nama agama mengajarkan: kasih, kebaikan, kedamaian, dll. Jika setiap agama mengkontraskan perbuatan-perbuatan antara kasih dan kejahatan, antara Allah versus Iblis, maka dari manakah asal-usul perbuatan jahat dan keiblisan yang didasarkan atas nama agama dilakukan? Atau mungkinkah perkerjaan-pekerjaan jahat atas nama agama bahkan Allah terjadi? Bukankah dalam hal ini manusia yang beragama sudah mengingkari tujuan keberagamaannya secara umum? Ternyata, ada juga para pembuat kejahatan dengan cara memakai tanda keabsahan agama atau bahkan "atas nama Allah". Padahal tindakan tersebut pastilah ciri khas keiblisan dalam pengalaman keagamaan manusia.

\section{Keberadaban Beragama demi Kelanjutan Masyarakat}

Di atas telah diajukan bahwa agama harus berfungsi di dalam masyarakatnya secara lokal, dan kemudian akan berperan melalui kesadaran antarpemeluknya dalam pembangunan sosial; atau eksistensi agama dan masyarakat berhubungan fungsional, maka pemeluk agama bertanggung jawab bagi peradaban manusia secara global. Artinya agama itu sendiri dalam dirinya tidak berfungsi dan tidak berguna apa-apa, kecuali ada pemeluknya. Artinya secara sosial, agama dapat saja didefinisikan hanya pada tekanan 'kegunaan' pragmatisnya daripada 'ketepatan' substansinya. Jadi aspek eksternal dalam tujuannya lebih ditekankan untuk bermasyarakat yang damai, dan perannya lebih menekankan aspek tugas tanggung jawab sosial para pelaku agama itu. Jadi keberagamaan dapat berperan di dalam pembangunan jika faedahnya berdampak pada pemeluknya masing-masing. Jadi didalam diri sendiri, agama tidak berperan apa-apa kecuali melalui pemeluknya. Peran keberagamaan manusia ini terkait dengan peradaban manusia dan dunia. 
Selanjutnya, secara sosial para pembuat kejahatan atas nama agama tersebut telah menyamakan Allah dengan Iblis atau sifat Allah identik dengan sifat iblis. Padahal para sekularis ateis pun tidak melakukan hal demikian. Orang yang tidak beragama formal justru lebih berperikemanusiaan, secara sadar mencintai dan mengusahakan kedamaian hidup. Ekses negatif agama formal inilah yang membuat beberapa orang tidak mau memeluk agama formal, meskipun tetap tidak bisa lari dari Allah, yang mungkin sama prinsipnya dengan tesis Bertrand Russel "bertuhan tanpa agama."12 Dalam arti membicarakan Allah tanpa menjadi religius atau tanpa harus memeluk satu agama tertentu, apalagi secara formal dan nominal atau agama yang terinstitusionalkan. Pendekatan Russel ini selain kreatif juga menunjukkan bahwa manusia tidak dapat lari dari Allah sekaligus kenyataan agama formal yang ditolak, karena kurang kontribusi pada peradaban manusia dan tidak dapat menopang secara positif moralitas umum masyarakat.

Selanjutnya, berdasarkan isu-isu tak berperikemanusiaan sebagai ekses negatif keberagamaan, kita harus sadar untuk memperkembangkan suatu studi agama dalam 3 hal: (1) "Mengembangkan perspektif global" pada lokal adalah dengan cara, (2) "Pengembangan suatu perspektif perbandingan", dalam pengertian saling memperkaya kehidupan kita dan dengan tujuan, (3) mencari cara kehidupan bersama untuk lebih manusiawi lagi dalam menghadapi kerusakan, kekerasan, dan kekacauan. ${ }^{13}$ Ketiga hal itu dapat menjadi positif dengan peradaban modern, jika manusia menyadari dan bertindak sebagai "makhluk berpikir" (homo sapiens) di dalam keperbedaan sosial dalam komunitas ketidaksesuaian dan perbedaan. Bahkan sebagai "makhluk akademis" (homo academicus), sebaiknya setiap

\footnotetext{
12 Bdk. prinsip-prinsip yang diajukan oleh Bertrand Russell dalam bukunya yang sudah diterjemahkan dengan judul Bertuhan Tanpa Agama, terj. (Yogyakarta: Resist Book, 2008).

13 Ibid., 13.
} 
permasalahan harus diselesaikan secara rasional dalam semangat persaudaraan umat manusia, bukan hanya kekeluargaan. Inilah yang membedakan manusia dengan binatang, yaitu: agama, kultur, masyarakat bahkan peradabannya. Arena keagamaan seharusnya bukan menjadi arena saling membinasakan antar manusia di dunia majemuk. Di sini perlu kedewasaan berpikir sebagai makhluk intelektual dan berbudaya.

Secara sosiologi agama diakui bahwa, "dalam berbagai kesempatan dan tempat di era modern, agama terus menjadi perekat kultural antarsesama kelompok yang dominan, ... dalam bangsa-bangsa baru, secara sosial, agama berperan besar dalam melestarikan kebudayaan-kebudayaan etnis, dan menjadi perantara antara komunitas asal dengan kelompok migran."14 Jadi agama sebagai faktor kebaikan umum tidak terlalu berfungsi baik selain kebaikan komunal dan seidentitas, bahkan jika berbeda langsung beroposisi dan bersaing. Seharusnya beragama bukan hanya bermanfaat bagi manusia di dalam budayanya, tetapi juga berfungsi di masyarakat dalam hubungannya dan dengan kemanusiaan yang lebih luas lagi dalam peradaban manusia.

Memang ada gagasan sekularisasi di dalam masyarakat agama, di mana kekuatan studi-studi sosial adalah sarana positif untuk mencegah disintegrasi suatu bangsa dalam masyarakat. Adalah sangat beralasan, ketika ada yang beranggapan pertumbuhan sekularisme pada masyarakat kota dikhawatirkan berdampak negatif terhadap 'eksistensi' agama itu sendiri. Memang secara radikal, pada giliranya sekularisme telah menolak tentang keberadaan Allah. Untuk itu, sekularalisasi dan sekularisme adalah dua hal yang berbeda. Sekularisasi maksudnya memisahkan agama dari urusan politik dan memisahkan politik dari urusan keagamaan masyarakat. Dengan demikian gagasan sekularisasi masyarakat dalam beragama adalah

14 Turner, Relasi Agama dan Teori Sosial Kontemporer, 391. 
sangat relevan bagi peradaban manusia, dan agama dapat terpelihara masa depannya dari serangan agama itu sendiri.

Sejak semula kita mengapriorikan sifat keagamaan dalam diri manusia yang bersifat metafisis atau non-natural otentiknya dari Allah. Artinya definisi supranaturalistik agama adalah suatu keniscayaan sebagai agama normal, bukan hanya kredo politik dan keyakinan filosofis ideologis yang naturalistik. Karena secara ideologis ada variasi-variasi keyakinan yang bersifat mistis dalam komitmen keberagamaan itu dijalankan, dalam cara-cara: kepercayaan (kredo), praktek (penyembahan pada supranatural), pengalaman (kontak individual dengan supranatural), pengetahuan (pengertian dan pengajaran dalam budaya keagamaannya), konsekuensi (akibat dan sebab tindakan-tindakan keagamaan kehidupan sehari-hari). ${ }^{15}$ Sedangkan agama natural atau non-formal secara ideologis menolak unsurunsur keagamaan tersebut. Dan semuanya selayaknya masuk ke dalam wacana pluralisme agama, baik secara struktural dan fungsional kemasyarakatan, namun bukan konfesional ajaran agama-agamanya.

\section{Prinsip-Prinsip Beragama demi Masa Depan Bersama: Perspektif Teologis}

Pemikiran praktis injili harus berani lebih maju, bukan soal wacana pluralisme agama yang telah usang, tetapi harus sampai pada mempertahankan peradaban manusia. Ini, khususnya dalam mengatasi ekses-ekses sempitnya keberagamaan warga dunia. Tema peradaban global adalah untuk menilai dan mengantisipasi keberlanjutan dunia manusia, sepanjang belum datang kiamat. Di sini kaum injili harus mewaspadai diri dengan kecenderungan ekstrimnya dalam pendekatan eksklusivisme agama yang bersifat konfrontatif. Hal itu muncul karena menghadapi non-injili

15 Ibid., 9-10. 
yang sering jatuh dengan pendekatan kompromistik dan sinkritistik dalam pendekatan pluralisme agama dan inklusivisme agama. Kita harus menghadapi kenyataan pluralisme agama dengan wajar dalam wacana sosial yang holistik.

Para teolog-seminarian harus terpanggil untuk mengatasi isu-isu peradaban manusia, khususnya dalam dunia agama-keagamaan yang rawan akan konflik. Dengan demikian teologi bukanlah kajian perenialisme konseptual semata untuk menonjolkan pengetahuan yang abstrak. Studi teologi harus membahas diskusi di awang-awang yang tidak berguna sebagai percakapan "omong kosong". Dengan demikian teologi Injili harus berpindah dari pendekatan dogmatik-tradisional, selama inia ini menuju pendekatan etik-kultural, karena lebih komprehensif untuk masyarakat majemuk. Agama-agama yang ingin bertahan tidak boleh menjadi ideologi saling berkompetisi dalam superiorisme saja. Adapun melihat prinsipprinsip injili dalam bermasyarakat plural harus disegarkan kembali dalam hal-hal berikut.

Membiarkan Agama-Agama Membanding secara Alamiah dalam Pergaulan Normal

Alasannya, keyakinan agama-agama tidak boleh dibandingbandingkan, baik pada tingkat praktis (kehidupan sehari-hari) maupun dalam studi akademis. Karena agama dan keberagamaan manusia adalah urusan pribadi (personal dan privat juga), walau tidak boleh diindividualisasikan - seperti fundamentalis -- karena sebagai manusia bersifat komunal dan societal.

Istilah "Perbandingan Agama" sebagai suatu studi sangatlah tendensius, lebih baik tidak diperbolehkan lagi ada dalam lingkungan akademis. Mungkin karena inilah, beberapa orang telah mengganti istilah "comparative religions" menjadi "world religions", walau seringkali isinya tetap 
sama saja, yaitu perbandingan tema-tema dogmatis dari agama-agama yang berbeda. ${ }^{16}$ Dalam keadaan ini, studi perbandingan agama-agama dalam kurikulum sekolah tinggi agama/teologi menjadi sesuatu yang harus ditantang sebagai produk imperialisme di masa lalu. Perbandingan seperti itu hanya soal superioritas suatu agama di dalam pendekatan eksklusivisme agama dari misi keselamatan. Memang biasanya kaum injili melihat agamaagama lain dari perspektif misiologis keselamatan semata-mata. ${ }^{17}$ Menurut saya, sudah saatnya kaum injili menimbang faktor sosial-budaya untuk menolong peradaban dunia yang lebih luas melampaui soal-soal penginjilan dan pertobatan. Hal ini mengingat bahwa pertobatan dan keselamatan sorgawi adalah soal anugerah Allah semata. Di sini kita menyarankan dialog yang natural antarumat beragama di dalam masyarakat, tidak perlu rekayasa akademis dan politis.

Namun popularitas "world religions" di dalam pendidikan tinggi telah menjadi salah satu studi yang diminati, karena motifnya adalah rivalisme agama. Mungkin label ini adalah usaha positif dari para sarjana dalam mengatasi isu eksklusivisme dan pluralisme agama. Jadi harus dipastikan bahwa memang pelajarannya adalah memperkenalkan agama-agama lain sebagai pengayaan umat manusia. Kalau tidak, lebih baik dihindari dan dikeluarkan dari studi kesarjanaan masa kini, karena tidak produktif bagi peradaban masa kini. Namun kalau harus mengajarkan agama yang lain, maka untuk pengayaan keilmuan, orang dari agama lain tersebut sampai

16 Ini suatu contoh yang baik bagi kita dari buku Sir Norman Anderson, Christianity and World Religions: Challenge of Pluralism (Downers Grove: InterVarsity, 1984). Semula buku ini berjudul Christianity and Comparative Religion (InterVarsity, 1970) yang pemikirannya berasumsi superiorisme agama Kristen dalam studi perbandingan agama-agama yang didasarkan pola peradaban Barat selama ini dalam prinsip orientalisme.

17 Buku ini adalah tipikal penjelasan Injili mengenai agama-agama dalam kaitannya dengan kekristenan, selalu didahului dengan perspektif alkitabiah, lalu agenda dan motif adalah misipenginjilan serta tujuan adalah keselamatan (pertobatan), Edward Rommen dan Harold Netland, eds., Christianity and The Religions: A Biblical Theology of World Religions (Pasadena: William Carey Library, 1995). 
dapat mengakui, "Ya memang benar, itu adalah (penjelasan) tentang agama saya" karena dalam mengajarkan agama lain, seorang beragama harus melepaskan kewajiban-kewajiban agamanya sendiri. ${ }^{18}$ Ini tentunya sulit, jadi lebih baik harus dilakukan oleh orang yang seagama dengan materi yang diajarkan, namun netralitas deskriptif bukanlah netralitas komitmen, yang tak terhindari. Selama ini agama telah dibandingkan secara tidak layak pada tingkat kepercayaan dogmatis terdalam yang adalah urusan pribadi dan tentunya paling sensitif. Karena beragama adalah hal penghayatan perseorangan, maka "agama saya tidak layak dibandingkan oleh orang beragama lain", karena pasti interes pribadi pembandingnya. Namun tidak banyak yang tahu bahwa studi perbandingan agama adalah sisa sisa kajian orientalisme Barat yang Kristen dan sekarang masih ditiru oleh kita dan agama lain juga.

Ini harus menjadi catatan kritis bagi Orientalis yang paling liberal sekalipun dalam studi agama-keagamaan masa kini. Karena ide bentrok peradaban dunia sekarang telah bergerser menjadi bentrok dunia Barat versus dunia Islam. Biar bagaimanapun imperialisme intelektual Barat jelas mempengaruhi cara pikir pelajar Asia. Selanjutnya kaum injili dapat mencermati dan belajar dari penjelasan sekarang, bahwa dapat dikatakan "Since 9/11, it has become clear that religion is part and parcel of the unfolding of twenty-firstcentury history. The contemporary world is shaped by religions"19 "In many ways we can regard both --religion and culture-- of these as separate and distinct, but they also overlap and have an impact on each other" 20 bahwa kita "at the heart... when we study religion, we should try not to analyse it as something abstract and set aside." ${ }^{21}$ Eksistensi agama

\footnotetext{
18 Lih. Togardo Siburian, Teologi Religionum Misioner: Pendekatan Injili pada Agama-agama Lain (Bandung: Penerbit STT Bandung, 2004), 21 dst.

19 Malorie Nye, Religion: The Basics, 1.

20 Ibid., 2.

21 Ibid., 3.
} 
dalam budaya manusia harus diperhatikan secara khusus dalam pendekatan sekaligus untuk peradaban manusia sekarang, bahkan di masa depan. Studi agama-agama harus di dalam kebudayaan manusia dan untuk membudayakan manusia di dalam beragamanya. Kalau tidak maka studinya akan merusak peradaban dalam kajian perbandingan agamaagama.

Termasuk juga label studi baru yang dikembangkan di Barat sekarang dalam program studi "comparative theology" yang dari outputnya terkesan sebagai perbandingan agama-agama juga, khususnya dengan Islam. Dari titik berangkat epistemologisnya, menurut Hans Abdiel, teologi komparatif adalah "dialog antariman berupa pengenalan yang kuat terhadap suatu tradisi religius tertentu dan kemudian berupaya membaca tradisi Kristen dengan cara pandang yang ditransformasikan melalui perjumpaan dengan tradisi religius yang lain. ${ }^{22}$ Mungkin maksudnya teologi transformatif, namun efek tendensius kata "komparatif' bagi umat beragama yang berkonflik secara historis-politis-ekonomis dan bentrok peradaban, sangat sulit melepaskan kecurigaan. Sikap kritis saya bukanlah suatu sinisme terhadap usaha-usaha para sarjana itu, karena pengalaman praktis pada tingkat akar rumput, tidak bisa mulus. Bahkan sudah terbukti gagal juga karena hasilnya digunakan untuk saling menyerang agama lain. Tiba saatnya kita mengakhiri pendekatan persaingan ini ala kajian orientalis masa lalu itu.

Sebenarnya perbandingan agama-agama secara natural sedang berlangsung dari kehidupan pemeluk agama-agama yang berbeda, di dalam dialog-dialog natural kehidupan. Sehingga perbandingan agama terlakukan secara layak pada acara dan tindakan keberagamaan manusia secara normal di dalam kehidupan riil. Kelak perbedaan akan ajaran dogmatisnya akan

22 Hans Abdiel Harmakaputera, Melepas Bingkai (Jakarta: Grafika Kreasindo, 2014), 104-5. 
jelas terlihat secara sosial dalam tingkah laku dan dalam hubungan antarpersonal di masyarakat. Jadi ajaran keagamaan tersebut terbandingkan dengan sendirinya dalam dinamika pemeluk agama, baik dalam kelakukan dan perlakuan terhadap orang beragama yang berbeda. Artinya sikap-sikap dari pelaku dapat dikaitkan secara formal dengan keyakinan agama di ruang publik. Dunia secara kasat mata dapat menilai sendiri agama macam apakah yang benar-benar baik dalam ajarannya. Ini seperti perumpamaan Lessing tentang cincin anak raja (pangeran), secara sosial agama dapat diajukan kepada kita secara sosiologi agama. Bahwa agama yang benar akan terbukti sendirinya dari kebaikan-kebaikan agamanya. Jadi semua umat beragama harus berlomba-lomba dalam kebaikan masyarakat, kalau tidak mau ditinggalkan pemeluknya yang semakin kritis dan terbuka. Setiap orang dapat mengerti sendiri lalu memperbaiki kehidupan beragamanya secara praktis dan pragmatis.

\section{Pemahaman Gereja Misional melampaui Misioner Semata}

Setiap agama mempunyai faktor dakwah atau misi atau syiar. Ini yang membuat agama menjadi misioner di masa lalu, sampai kebablasan hanya pada soal populasi pemeluk agama mengganti agama-agama orang lain secara tidak layak demi tugas misionernya. Demikian juga sampai sekarang ini membuat banyak konflik, karena setiap orang senang kalau ada orang berpindah ke agamanya, demikian juga sebaliknya sakit hati kalau ada orang seagamanya masuk agama orang lain. Kalau ini diumbar pasti memunculkan konflik, apalagi kepindahan disertai dengan kesaksiankesaksian perbandingan agama yang nadanya bermusuhan. Padahal agama soal pribadi, terserah saja mau berpindah-pindah asalkan jangan menjelekjelekkan agama yang ditinggalkannya. Sudah waktunya kita mengubah implikasi unsur misi agama itu dari misioner kembali ke misional. Awalnya gereja Kristen lebih bersifat misional ketimbang misioner. Tepatnya faktor 
misional adalah inti iman yang akan berkonsekuensi lembut pada agama yang misioner, bukan sekadar agresivitas agama, layaknya kebiasaan sektesekte agama yang baru muncul.

Aspek misi atau dakwah dalam agama-agama tidak terhindarkan, maka implementasinya dalam kata sifat misional bermakna lebih netral dalam deskripsinya dan positif fokusnya di dalam dampak kebaikankebaikan agama di dalam masyarakat. Ini disebut "agama publik". Karena di atas kita sudah menegaskan bahwa agama-agama yang berbeda tidak boleh dibanding-bandingkan secara langsung dan sengaja bermusuhan, maka biarlah agama-agama yang berbeda itu membandingkan dirinya sendiri secara normal dan alamiah dari pelaku agama. Sehingga aspek misi atau dakwah dari agama menjadi lebih lembut dan baik di masyarakat. Peran misional ini secara praktis ada di kehidupan bersama secara kebangsaan. Karena kesannya studi perbandingan agama selama ini lebih mengedepankan gereja misioner, maka pada kondisi sekarang ini agamaagama harus menekankan lebih tugas misional. Implementasi unsur misi agama harus melampaui usaha menambah populasi saja. Misi agama harus damai dan memberi pengaruh-pengaruh kebaikan demi peradaban manusia dalam kesetaraan dan sepenanggungan sebangsa.

Di sini kita harus positif memahami kedaulatan Allah dan keberadaan orang lain. Walau secara sosio-politik, kekristenan dikategorikan sebagai agama juga setara eksistensinya dengan agama-agama yang ada. Demikian halnya dengan Gereja Kristen selalu dipahami sebagai organik yang melampaui organisasi. Untuk itu orientasi-orientasi kewajiban misioner injili harus menolak agresivitas agama Kristen. Di sinilah pendekatan akomodasi teologis menjadi sangat penting berdasarkan prinsip inkarnasi Kristus serta garam dan terang dunia. Akomodasi menyarankan toleransi aktif, yaitu toleransi adalah suatu kewajiban, bukan hak. Sekarang dan di sini, seluruh manusia harus ikut berjuang untuk mempertahankan peradaban ini, sebelum Kristus datang kembali. 
Prinsip gereja misional bukanlah antimisioner, tetapi lebih lengkap dalam prinsip Kristen mencakup sekaligus melampaui tugas misioner selama ini. Mengingat usaha misi sekarang sering dipandang sederhana secara gaya Barat sebagai "zending" ke ujung-ujung bumi dan seberang lautan dan segala bangsa dan tempat. Misi sekarang memang harus kembali diperluas maknanya, bukan saja sekadar tugas pengkristenan dunia, tetapi secara sederhana bagi gereja-gereja lokal adalah "being mision" artinya everything is mission di mana pun, kapan pun, siapa pun we are sent to do something walau "(mission is) not everything". Jadi misi tetap sebagai tugas umum di tengah pekerjaan khusus ${ }^{23}$ mission tanpa compassion, seperti memberi sisa-sisa makanan kepada orang lain tanpa rasa bersalah, memberi orang yang membutuhkan karena merasa tidak enak untuk membuangnya. Ini adalah menghinan prinsip belas kasihan Kristen itu sendiri di dalam misi. Usaha misi menjadi sangat sarkastik seperti kalimat berikut, "Bisakah kami mengirimkan lima kacang ini, atau jeroan dan bawang putih ini (ke Afrika)? Atau "Kami dengan senang hati mengorbankan makanan yang tidak kami sukai ini demi anak-anak yang kelaparan." ${ }^{24}$ Sebenarnya misi Kristen berdasarkan kasih agape tanpa jasa, walau harus mengurangi harta kita.

Menekankan Fokus Etis daripada Apologetis (pada Isu-isu Kemanusiaan)

Selain aspek misi atau dakwah, tidak bisa disangkal bahwa setiap agama mempunyai unsur apologetisnya juga. Bahkan kajian yang berpendekatan fenomenologi agama yang dianggap paling netral pun tidak

\footnotetext{
23 Kevin DeYoung dan Greg Gilbert, What Is the Mission of the Church: Making Sense of Social Justice and Shalom and Great Commission (Wheaton: Crossway Book, 2011), 19-20.

24 Paul Borthwick, Great Commission Great Compassion (Mengikut Yesus dan Mengasihi Dunia, terj. (Surabaya Perkantas Jatim, 2016), 60.
} 
bisa menghindarinya. Namun yang dimaksudkan dengan apologetika sebagai filosofis adalah pada tataran world view di balik pemikiran ucapan dan tindakan seseorang, dan yang selalu berupa isme-isme tertentu yang bersifat religius juga. Namun dalam perdebatan-perdebatan antaragama di dunia maya, nyata sekali apa yang dianggap apologetika sebagai "pembelaan iman" telah tercoreng dengan penghinaan kepada agama lain dengan kata-kata sadis, kasar, jorok, kotor, makian dan cacian. Jadi apapun yang dimaksudkan dengan apologetika dialogis telah menjadi debat-kusir yang tidak habis-habisnya, serta memperuncing permusuhan di kalangan orang beragama. Jadi tugas apologetika injili masa kini dalam tugas misional hanyalah melakukan afirmasi saja, bukan komparasi. Cara berapologetika yang lebih baik dalam konteks ini adalah penjernihan dan penegasan, bukanlah pembelaan apalagi pernyerangan. Di sini nilai-nilai kebaikan etis agama menjadi penting bagi injili.

Karena apologetika sudah disalahgunakan dengan memasukkan unsur perbandingan agama, maka lebih baik tindakan dan langkah apologetika dalam lapangan masyarakat agama dihentikan, karena hanya soal persaingan antaragama yang berbeda. Sudah saatnya "dialog 'unapologetic'”' 25 dengan pengertian bahwa jenis dialog ini tetap tidak sama dengan apologetika dialogis yang adalah tindakan teknis dari dialog apologetik. ${ }^{26}$ Berbeda dengan dialog apologetik, apologetika dialogis dilakukan secara pemahaman etik dan menekankan pendekatan etisnya. Sepintas memang terlihat ada unsur-unsur dialog dalam pendekatanpendekatan perbandingan agama di atas, namun tetap isinya bukan

\footnotetext{
25 Lih. juga sebagai agen transformasi masyarakat, gereja dan teologi, Howard A. Snyder, Global Good News: Mission in A New Context (Nashville: Abingdon Press, 2001), 137.

26 Di internet sekarang terlalu banyak mahasiswa umum memakai kata "apologetika" atau dialog apologetis untuk berdebat agama secara kasar dan jahat, konon bangga sedang membela agamanya. Yang ada hanya caci maki dan permusuhan dan membuat agama menjadi si jahat pemicu kebencian manusia.
} 
pertentangan agama tetapi informasi yang lain saja. Jadi kajiannya menjadi etika sosial sebagai studi adalah studi intelektual, namun karena pengertiannya sangat positif di masyarakat umum, ${ }^{27}$ maka terobosan pemikiran harus diambil untuk mengatasi konflik keberagamaan. Di sini dialog antarumat beragama masih tetap diperbolehkan sebagai suatu yang niscaya bagi makhluk sosial agama yang beradab-budaya. Jadi dialog agama ada perlunya, namun bukan dialog komparatif tetapi dialog etis demi kemaslahatan manusia bersama. Peran umat beragama dalam masyarakat plural adalah terus berdialog, fokus etis sosial. Di sini konsep injili mengenai "contextualism ethics" harus mendapat tempat serius dalam situasi permasalahan sosial keagamaan dibandingkan dengan "absolutism ethics" yang melampaui prinsip “individualisme” menuju komunitas yang lebih majemuk dan global wilayahnya. ${ }^{28}$ Menurut D'Costa, di era ini lebih penting dipertanyakan kekristenan dalam relasinya begitu negatif dengan agama-agama dunia adalah "...The question are not simple theological and pastoral (can non Christian be saved?); but also practical and political (how should Christian relate to religious pluralist in public square?)"29 Untuk itu, "if it is the argued that the Christian missionary imperative will lead to a clash of civilization, as Islam... The manner in which its religions understand and pratices its universal mission is a matter to be evaluated" 30

\footnotetext{
27 Ini tidak dimaksudkan untuk mengubah posisi saya dalam buku yang berjudul Kerangka Teologi Religionum Misioner, 133 dst. Mengingat apologetika adalah memang tugas khas injili, selain tugas misionernya, namun tempatnya hanya dikendorkan sedikit dalam lapangan umat beragama yang sensitif akan konflik dan menyarankan untuk mengedepankan pendekatan etik pada persoalan kemanusiaan bersama untuk tugas dialognya.

28 Max L Stackhaouse, dkk. Christian Social Ethics on Global Era (Nashville: Abingdon Press, 1995), 64-5.

29 Gavin D'Costa, Christianity and World Religions: Disputed Question in Theology of Religions (Malden, Oxford: Willey Blackwell, 2009), x. Walau D'Costa masih melihat bahwa peperangan agama selama ini masih dalam comparative religion di sekitar ajaran problematis dari agama agama), xii.

30 Ibid., 138.
} 
Ia berusaha mempertanyakan lagi usaha misioner selama ini. Penerapan etika injili dalam kewajiban dan kemutlakan harus juga menimbang dalam kebajikan dan toleransi yang lebih luas terhadap masyarakat majemuk. Bukan hanya legalisme dan fanatisme agama tertentu. Kita sudah melihat pada titik ini, etika dasar dan global bagi agama-agama pada prinsipnya tidak salah sama sekali. Hanya eksesnya dapat terjatuh juga dalam pencampuran agama dan sering dituduh sebagai sinkretisme. Maksud injili mengenai etika global tidak demikian. Kaum injili harus membuka 'kran' pemikiran yang mandeg untuk mengalirkan pemikiran-pemikiran keterbukaan dalam prinsip moral dan rohani Kerajaan Allah dalam terang Injil yang otentik. Jadi bukan injil agama fundamantalis atau injil sosial ekumenis.

Disarankan dialog etis keagamaan lebih baik di dalam dunia akademis dan praktis, di mana orang beragama yang berbeda harus berusaha saling memahami dan menerima perbedaan, bukan hanya sekadar mencari kesamaan antaragama. Untuk itu tujuan dialog sama sekali bukan untuk mencari menang-kalah dalam superiorisme agama, tetapi menjadi sumber informasi yang memperkaya cara pandang bersama dalam toleransi. Untuk itu dialog hanya sebagai media dalam arti yang paling umum, yaitu sarana untuk saling berkomunikasi. Jadi kegiatan dialog antaragama pada tingkat perbedaan bukannya tidak mungkin dilakukan, namun memerlukan hati yang lapang, adil, pikiran terbuka, obyektif, serta intelek. Di sini toleransi adalah suatu kewajiban dan tugas manusia beragama, bukan hak. Faktanya selama ini, hal itu hanya dapat dilakukan kalau orang tersebut sudah sangat matang tentang agamanya dan dalam agamanya, ditambah dengan berbudaya mulia dalam jiwa demokratis serta bersifat akademis; sehingga dapat menerima perbedaan sebagai kekayaan hidup.

Namun beberapa orang memakai dialog antaragama sama dengan perbandingan agama; yang lain menolak dialog agama tetapi masih mengajarkan perbandingan agama-agama secara ekstrim. Sepintas memang 
terlihat ada unsur-unsur dialog juga dalam pendekatan-pendekatan perbandingan agama di atas. Namun yang dimaksudkan di sini adalah dialog khusus antarpemeluk agama sebagai suatu usaha sadar serta terstruktur dalam memahami dan menyelami agama-agama yang ada dalam persamaan-persamaan ajaran dan pengalaman-pengalaman yang sama. Bahkan untuk lebih otentik disarankan juga dialog sampai pada tingkat perbedaan yang paling ekstrim sekalipun, namun tetap toleransi, tanpa tersinggung dan tanpa menghina. Ini memang tujuan ideal dalam dialog agama pada masa kini, khususnya di dalam pembicaraan etika global dari Parlemen Agama-agama Dunia. Di sini, pandangan bahwa pluralisme sebagai pendekatan teologis yang diajukan Hans Kung dkk, bukanlah 'jalan konservatif' yang saya pegang. Namun tidak perlu harus berpaham pluralisme agama dulu (berkarakter universalisme soteriologis) untuk menerima etika global. Karena pada dasarnya di dalam kekristenan ada nilai-nilai universal yang didasarkan pada wahyu umum dan anugerah umum ilahi. Gagasan etika global bermain dalam arena umum tersebut, seperti: keadilan masyarakat, kedamaian dunia, hati nurani manusia dan agama-keagamaan, moral etis, dll.

Keseimbangan Komitmen Iman dan Toleransi Beragama dalam Teologi Agama-Agama

Injili adalah kaum yang setia pada iman ortodoks. Walau ada komitmen diri tersebut, namun harus tetap melihat fakta-fakta keberagamaan manusia secara dinamis di tengah-tengah kehidupan. Jadi komitmen iman dan toleransi beragama berjalan bersama di dalam kehidupan bermasyarakat secara umum. Ini dua hal yang berbeda, namun dapat dilakukan bersama dalam pemahaman bergereja yang lebih inklusif dan tidak menolak nilai-nilai iman partikular di dalam Kristus. Ini adalah keunikan Kristen, namun keunikan tidak sama dengan eksklusivisme 
agama sebagai pendekatan ekstrim. Secara spesifik, teologi religionumnya didekati dari luar lingkungan sosial agama-agama. Jadi studinya tidak bisa bebas nilai lagi. Komitmen iman yang spesifik dan personal, namun dapat menerima keunikan agama lain tanpa tersinggung dan tidak memaksakan ajaran agamanya. Toleransi adalah suatu kewajiban, bukan hak. Dengan demikian tugas peradaban yang berbudaya luhur antarmanusia beragama dapat dihayati di dalam keunikannya sendiri-sendiri.

Dalam presuposisi injili, studi teologi berbeda dari presuposisi studistudi sosial. Teologi injili mengandung komitmen iman karena beberapa faktor keunikan Kristen. Secara ontologis, iman Kristen berlainan dengan agama-agama; karena kekristenan adalah anugerah keselamatan dari Allah saja, sedangkan agama adalah usaha keselamatan manusia secara rasional. Di mana agama dimengerti sebagai "perbuatan baik" kepada Allah; sedangkan kekristenan adalah anugerah Allah kepada manusia. Iman adalah inisiatif Allah menjangkau manusia dengan iman yang menyelamatkan.

Usaha berteologi agama-agama melakukan refleksi sistematis atas hubungan antara orang yang beragama Kristen dan yang beragama lain di masyarakat. Suatu masyarakat selalu dilihat dari aspek fisiknya, karena relasi antarmanusia atau antarkelompok orang beragama secara observasi sosiologis. Sedangkan aspek metafisiknya dilihat dari studi teologisnya, atau sedikitnya studi divinitas, yaitu melihat konsep-konsep keyakinan dan kepercayaan agama. Namun keagamaan Kristen yang otentik berdasarkan nilai-nilai intrinsik bukan hanya aktivitas yang bernilai ekstrinsik dalam ritual dan peraturan agama. Jadi selain bersifat spiritual juga berdimensi institusional, maka kekristenan pun di dalam masyarakat mengandung keagamaannya juga.

Studi teologi selalu ada komitmen iman yang partikuler dalam konteks bergereja yang inklusif, sekaligus bersifat eksklusif dalam arti keunikan Kristen. Catatannya adalah inklusif tidak perlu menjadi 
inklusivisme yang sinkritistik dan tidak menjadi eksklusivisme yang konfrontatif. Jadi tetap penting melihat keunikan Kristus asalkan dihayati dan diterapkan dengan adil. Selama ini kaum injili menolak pluralisme teologis dan penerimaan pluralisme sosial sebagai suatu kenyataan yang sehat untuk gereja. Selama ini kaum injili mengerti wacana pluralisme sebagai wacana studi-studi sosial untuk mendekati ekses-ekses negatif agama di masyarakat dalam rangka dicari resolusinya berdasarkan kemanusiaan, keadilan, kebangsaan, kebaikan, kebersamaan, dan persaudaraan manusia. Tentunya yang dicari adalah keumuman dalam latar belakang kesatuan konteks, tidak perlu sampai pada kesamaan ajaran agama yang berbeda. Jadi pengayaan teologi, khususnya relasi orang Kristen dalam keberagamaannya, dalam situasi multiagama berdasarkan penciptaan ilahi sebagai anugerah umum.

Netralitasnya yang penuh tidak bisa dihindari, karena tidak bisa menyangkali kecenderungan komitmen diri sendiri pada agama sendiri, baik secara pikiran, perasaan, dan kemauannya. Kita sudah melihat bahwa faktor "netralitas" hanya dimengerti sebagai tidak memihak secara adil dan seimbang (fairness). Ini yang dinamakan "netralitas" deskriptif. Namun dalam teologi, netralitas demikian dapat membosankan juga apalagi untuk kajian lanjutan yang membutuhkan pikiran lebih kritis. Oleh karena itulah teologi Kristen mengarahkan refleksi pada isu-isu kontekstual kemanusiaan dalam berkeagamaan. Karena teologi adalah ilmu integral, jadi kajiannya bersifat komparatif juga, tidak seperti ilmu-ilmu yang mengklaim otonom dan diotonomkan hanya sebatas ilmu khusus (spesifik). Dengan pendekatan teologis ini, maka komitmen dapat tetap diakui, karena berteologis revelasional selalu harus berdasarkan: iman, wahyu, tradisi Kristen, dan akal, secara integralistik tanpa harus mengabaikan konteks yang sedang dihadapi sekarang. 
Kepemimpinan Kenabian Melampaui Keimamatan dalam Umat Beragama

Pentingnya sifat kepemimpinan profetik dalam relasi antaragama dalam masyarakat plural adalah pembebasan hidup manusia dari kungkungan dan ancaman tradisi agama yang sempit akibat upaya indoktrinasi selama ini. Kepemimpinan imamat bukannya tidak penting, khususnya di dalam internal agama sebagai sumber pengajaran. Tetapi pengajaran itu sering tidak dibawa kepada agama atau Tuhan, melainkan kepada sang imam itu sendiri. Semuanya serba kepentingan imam semata yang mengklaim sebagai utusan dan satu-satunya penafsir kebenaran ilahi. Sedangkan kepemimpinan profetik lebih mengarah pada keprihatinan dan penanggulangan isu-isu spesifik di masyarakat, serta kemanusiaan secara bersama yang sedang terhimpit oleh kehidupan. Kepemimpinan profetik membawa kesegaran baru dalam pembebasan, seperti pesan yang dibawa oleh pemula. Ia membuat kehidupan umat bergairah, jujur, adil, dan bertanggung jawab. Namun kepemimpinan profetik yang dimaksud di sini adalah kepemimpinan profetik dalam dunia maju dan peradaban besar yang multiperadaban.

Ini adalah pilihan masa kini sebagai "tugas profetik", suatu kepekaan pada situasi khusus dan tertentu dalam pergumulan setempat dalam kontekstualisasi teologis spesifik doktrin terapan. Pendekatan kenabian melampaui kenabian yang macet dalam perang peradaban selama ini. Di dalam agama tidak ada salahnya kepemimpinan imamat, tetapi agama tidak sendirian di dalam masyarakat, bahkan hidup bersama dengan yang lain dalam tindakan dan suara kenabian untuk membela yang menderita, terhina, demi keadilan dan kebenaran secara sosial. Ini suatu revolusi injili sekarang juga dalam dunia agama-agama sekarang. Pentingnya kategori kenabian ini karena kesadaran bahwa karya Kristen sekarang bukan hanya soal: 1) proklamasi: kabar baik yang terbuka bagi orang yang mau percaya 
Injil dengan sukarela, 2) belas kasihan Kristen: untuk kepedulian holistik kebutuhan manusia juga 3) keadilan: pembebasan dari segala jenis penindasan dan eksploitasi manusia lain dan menentang segala jenis penindasan, ${ }^{31}$ apalagi karena diskriminasi agama.

Sifat kenabian dan keimamatan berbeda orientasi dan fokusnya. ${ }^{32}$ Kenabian bersifat membela kebenaran, keadilan, membela orang kecil dan marginal di dalam suara pelayanan kepada pengikut. Fokusnya membebaskan, memerdekakan yang tertindas oleh kebiasaan yang sudah mapan. Karya kenabian sifatnya pembebasan, seperti yang dilakukan para nabi: Musa, Yeremia, Buddha, Konfusius bahkan Muhammad. Sedangkan kepemimpinan imamat selalu memerintah dengan fatwa kepada umat: keras, kaku, tidak berbudaya peradaban dan mengharamkan, mengkafirkan. Kepemimpinan imamat sangat sempit dan tidak terbuka secara kontekstual, cenderung mengikat dan memperhamba orang beragama. Pendekatan profetik ini menolak konsep individualisme agama. Namun profetik lebih tajam lagi dalam mengatasi isu-isu manusia yang lebih spesifik pada problem kemanusiaan dalam masyarakat. Selanjutnya menurut Prof. Amin Abdullah dalam pengantar suatu buku, solusi keimaman dalam priestly religious policies seringkali tidak sejalan atau tidak seirama dengan solusi kenabian (prophetic religious policies). ${ }^{33}$

Sebagai tanggung jawabnya, masyarakat memerlukan kepemimpinan profetik bukan hanya kepemimpinan keimamatan saja. Jenis kenabian menekankan kemaslahatan dan keprihatinan manusia secara umum, sedang

\footnotetext{
31 Michael Stearns, Belum Selesai, terj. (Surabaya: Perkantas Jatim, 2014), 214.

32 Secara umum gagasan ini sudah pernah saya munculkan dalam "Manusia Agama dan Masyarakat: Suatu Wacana Menuju Dialog Multi-peradaban Global" Jurnal Societas Dei Vol. 1 No. 1 (Oktober 2014). Awalnya ada dalam disertasi saya dengan judul "Prinsip Kenabian Gereja pada Fenomena Penutupan Gereja di Era Reformasi Politik Indonesia" (2013).

33 Dia mengatakannya sebagai fatwa politik keberagamaan klergi atau ulama dalam Iswandi Syahputera, Komunikasi Profetik: Konsep dan Pendekatan (Yogyakarta: Simbiosa Rekatama Media, 2007), iv.
} 
keimamatan untuk memperkuat diri sendiri saja; yang pertama didasarkan pada keprihatinan buttom up, dan yang kedua didasarkan pada perintah top down. Bahayanya, kepemimpinan keimamatan tidak mengindahkan problem kemanusiaan umum di masyarakat selain golongannya sendiri. Ini adalah kondisi "kepatuhan buta" yang didasarkan pada "klaim kebenaran mutlak"34 para imam agama. Kenabian akan mempertimbangkan situasi konkrit yang sedang terjadi dalam pergumulan masyarakat. Suara bebas dan riil dari keadaan masyarakat secara aktual demi manusia itu sendiri.

Menyarankan Pendekatan Partikularisme Iman Bukan Eksklusivisme Agama dalam Pluralisme Masyarakat

Secara teologis, berkeagamaan adalah hak privat manusia walaupun prakteknya di publik harus menimbang keberadaan yang lain. Jadi agama dalam hal ini bersisi dua, soal privat sekaligus soal publik, personal sekaligus sosial. Setiap manusia yang merusak relasi sosial agamanya, apalagi dalam konflik agama, merusak hakikatnya sebagai makhluk intelek, karena hidup tanpa identitas dan solidaritas manusia agama. Di sini pentingnya prinsip masyarakat beradab sebagai suatu kompleks yang terdiri dari relasi, peran, nilai, hirarki sosial dari organisasi kepelbagaian karakter dalam motif, orientasi, dan cara yang seringkali saling bersaing bahkan beroposisi, dll.

Prinsip pluralisme sosial dan struktural dalam masyarakat majemuk adalah suatu yang niscaya bagi negara bangsa seperti sekarang. Kalau kita melihat, Pancasila sendiri berdasarkan prinsip pluralisme dalam Bhinneka Tungga Ika yang dibutuhkan oleh bangsa multiagama ini. Namun pluralisme sosial sebagai suatu kenyataan dan wacana sosial tidak sama dengan pluralisme agama sebagai pendekatan terhadap yang berbeda.

\footnotetext{
34 Lih. Kimball, Kala Agama Menjadi Bencana, pasal 2, 3, 4. Kimball mengobservasi ketiganya
} secara luas dengan contoh-contoh, tindakan, dan konsekuensi jahat bagi manusia sedunia. 
Pemakaian ekstrim konsep pluralisme dalam suatu pendekatan agama, yang menyamakan semua agama yang berbeda, lalu menjadikannya satu keagamaan global dan universal, bukanlah tujuan wacana pluralisme sosial selama ini. Jadi pluralisme di sini adalah soal kebersamaan hidup dalam kesederajatan di dalam suatu masyarakat majemuk. Kaum injili dapat menolak pendekatan ideologis dari eksklusivisme agama yang selama ini dianutnya sama seperti menolak pendekatan pluralisme agama, termasuk pendekatan inklusivisme agama, karena mengencerkan identitas Kristennya yang privat dan personal dalam masyarakat. Pendekatan eksklusivisme agama adalah ekses negatif dari pemakaian ekstrim keunikan agama-agama dan partikularisme iman Kristen. Akhiran 'me' adalah suatu sikap ideologis yang sifatnya kompetitif. Realitas eksklusif Kristen sebagai sifat normal agama-agama yang seharusnya tidak dijadikan eksklusivisme dalam ideologi yang fanatik dan konfrontatif.

Kenyataan inklusif-eksklusif dapat dirumuskan menjadi suatu pendekatan gabungan sekaligus dalam pendekatan partikularisme iman, karena keunikan Kristus sendiri. Ini dalam pendekatan akomodatif injili yang mengingat iman personal untuk keselamatan di dalam Kristus saja. Iman adalah urusan pribadi dan khusus yang tidak dapat dibandingkan dan dikompetisikan, selain dihayati dan dijalankan di dalam kehidupan. Pendekatan partikularisme iman tanpa harus menjadi eksklusivisme agama yang keras dan fanatisme yang membuat konflik di masyarakat se-bangsa. Sifat saling mencurigai antaragama seharusnya disingkirkan, karena agama adalah masalah personal namun daerah privat, tetapi bukan individual saja. Karena personal harus terkait dengan komunal dan sosietalnya. Sedangkan individual hanya bersembunyi di balik tembok (getho). Gereja ada di masyarakat sebagai agen transformasi sosial dalam prinsip garam dan terang bersifat eksklusif dan inklusif sekaligus. Di sini ekslusif-inklusif adalah bentuk akomodasi seimbang dalam toleransi beragama, sekaligus menunjukkan sifat partikularitas kepercayaan iman Kristen di dalam 
keselamatan. Ini bukan suatu paksaan atau sikap superioritas agama dan dipakai sebagai sarana persaingan agama, tetapi sebagai sarana mengucapan syukur.

Aspek Spiritualitas Personal Melampaui Religiusitas Individual dalam Kebersamaan Antarpemeluk Agama yang Berbeda

Di sini kita membedakan konsep spiritualitas tidak sama dengan religiusitas, bahkan seringkali berlawanan dalam prakteknya. Seorang yang bersikap spiritual mengalir dari secara personal terkait kebaikan internal dan nilai intrinsiknya yang jujur, lembut, baik hati terpancar keluar. Sedangkan seorang religius hanya menekankan kondisi luar seseorang dalam aturan-aturan formal agama yang terlihat orang lain biasanya menjadi munafik seperti agar mendapat pujian, dan cenderung keras, kaku, fanatik, legalistik, sempit dalam soal-soal beragama yang kelihatan saja. Orang fanatik dan radikal selama ini sangat religius namun sama sekali tidak baik secara rohani. Adalah fakta kecenderungan seorang religius, semakin menguatkan agama semakin gelisah dan menghakimi orang lain berdasarkan patokannya sendiri. Kemunafikan hidup adalah ciri orang religius yang cenderung memaksakan kehendak. NT Wright, secara umum melihat keprihatinan tersebut bagi warga dunia sekarang, seperti yang dikatakannya sebagai "kejahatan baru" dan "yang paling tidak peduli dan tidak bertanggung jawab (secara sosial)" dan "garang tanpa pertimbangan". ${ }^{35}$ Bahkan peribadatan agama reguler menjadi sangat sepi kebajikan manusia. Religiusitas agama tanpa spiritualitas agama menjadi palsu dalam beragama formal. Dalam hal ini, tidak banyak orang yang sadar bahwa seorang religius justru membahayakan masyarakat majemuk. Namun faktanya sudah dapat dilihat dan dirasakan secara kasat mata dalam

35 N.T. Wright, Hati dan Wajah Kristen: Terwujudnya Kerinduan Manusia \& Dunia terj. (Jakarta: Penerbit Waskita, 2012), 15. 
tindakan-tindakan yang tidak adil, bahkan tak berkemanusiaan. Di sini orang yang kuat tentang agama belum tentu mendalam apalagi meluas dalam agamanya. Tetapi kalau kerohanian sifatnya mendalam secara internal dan meluas dalam kemanusiaan.

Terkait dengan ibadah Kristen, misalnya, Mark Liberton melihat kondisi agama dan praktek agama dalam ibadat menghindari suara kenabian, ${ }^{36}$ tidak peduli persoalan riil di dalam kehidupan, bahkan dikatakan orang beragama yang telah gagal mempraktikkan. ${ }^{37}$ Ibadah agama ramai namun tidak menghiraukan kehadiran orang lain, kekudusan ibadahnya kehilangan sesama. Ternyata sikap radikal dari fundamentalis agama ini masih menjadi momok zaman ini. Tentu peringatannya untuk kekristenan injili harus menghindari dirinya sendiri dari sikap negatif dan menolak prinsip-prinsip fundamentalisme agama sebagai suatu musuh bersama umat manusia. Kaum Kristen gerakan iman harus tetap mengingat prinsip berikut, bahwa suatu kabar baik hanya dapat disebut "kabar baik" dalam misi gereja, bila ada dampak baik bagi manusia di dunia ini, dalam hal mentransformasi manusia dan masyarakat." 38 Pentingnya spiritualitas yang otentik bukan sekadar ritual formal dan ajaran kaku, melainkan keluar dari kesalehan rohani yang halus dari dalam diri. Spiritualitas adalah suatu yang melampaui agama dan menembus pada pengharapan dalam keselamatan iman. Sayangnya, sampai sekarang tema "spiritualitas" adalah sebagai religiusitas saja dan dipakai secara bergantian dalam arti yang sama, dalam sebagai "mata air" yang tersembunyi ini. ${ }^{39}$ Faktanya, sering kali religiusitas yang 'tinggi; lebih menyempit dalam agama privat yang ekstrim dan fanatis. Sedangkan spiritualitas lebih bersifat dinamis dan terbuka di

\footnotetext{
36 Mark Labberton, Bahaya Ibadah Sejati: Sebuah Panggilan Memerangi Ketidakadilan terj. (Surabaya: Perkantas Jatim, 2011), 24.

37 Ibid., 127.

38 N.T. Wright, Hati dan Wajah Kristen, 14.

39 Ibid., 29.
} 
tengah komunal dan masyarakat yang plural.

Kekudusan injili harus memikirkan kesalehan sosial dalam prinsip kebajikan iman Kristen sehari-hari. Jadi kaum injili tidak mengabaikan kekudusan personal, namun harus tetap terkait dengan kesalehan hidup komunal dan sosial. Hal ini dikarenakan, "Jika (kita) kira menjadi Kristen (hanya) sekadar mengucapkan doa atau ke gereja, maka (kita) telah mencampurkan anugerah sejati dengan anugerah murahan." 40 Jadi sangat benar juga kalau dikatakan, "tidak perlu menjadi pietis, legalis dan fundamentalis (dulu) dalam mengejar kekudusan." 41 Kekudusan rohani adalah prinsip hidup murni dalam kesalehan yang dinamis bukan legalisme agama; di sini spiritualitas melampaui religiusitas, bukan anti-religiusitas. Jadi dalam konteks agama-agama di masyarakat, seorang religius belum tentu spiritual, walau spiritualitas Kristen mungkin mengandung sampai aspek religius tertentu. Namun ini suatu aspek religiusitas khusus dalam iman dan Roh Kudus, dan bukanlah religiusitas umum dalam tatacara beragama saja.

\section{Penutup}

Ini terkait dengan sikap etis daripada apologetis, tugas profetik gereja di masyarakat dan komitmen umat dalam toleransi beragama. Di mana membiarkan agama-agama terbanding dengan sendirinya di dalam pergaulan masyarakat sehari-hari. Ajaran agama-agama itu biar terbanding secara natural dan wajar dalam relasi-relasi kemanusiaan di tempat publik dan positif. Ini adalah penting di dalam masyarakat plural yang berperadaban pada masa kini.

\footnotetext{
40 Kevin DeYoung, Lubang dalam Kekudusan Kita: Mengisi Lubang akan Hasrat Injil dan Mengejar Kekudusan, terj. (Surabaya: Literatur Perkantas Jatim, 2015), 34.

41 Ibid., 24.
} 
Ekses selalu negatif namun tetap harus ada rasionalisasinya, agar dapat dicari resolusi secara beradab. Yang terakhir ini pun dapat dikerjakan oleh manusia sebagai makhluk akademikus dan makhluk intelektus. Di sinilah kita tidak takut adanya konflik sosial yang datang akibat pergaulan multikultur, namun harus ada alasan rasionalnya dalam manusia, sehingga manusia dapat belajar menjadi makhluk beradab.

Selanjutnya agama masih mempunyai masa depan dalam kebudayaan dan peradaban. Karena sebagai makhluk agama, manusia sekuler tidak dapat mengisi kekosongan makna eksistensi hidup yang tertinggi dengan sesuatu yang materialistik saja, sedangkan dampak negatif yang sebenarnya tidak perlu adalah reaksi fundamentalisme agama dalam menghadapi sekularisme. 